\title{
Specific recognition of a transcriptional element within the human H-ras proto-oncogene by the p53 tumor suppressor
}

\author{
DEMETRIOS A. SPANDIDOS ${ }^{1,2}$, VASILIS ZOUMPOURLIS ${ }^{1}$, GEORGE ZACHOS $^{1.2}$, \\ SARAH H. TOAS ${ }^{3}$ and THANOS D. HALAZONETIS ${ }^{3,4}$
}

\begin{abstract}
${ }^{1}$ Institute of Biological Research and Biotechnology, National Hellenic, Research Foundation, Athens; ${ }^{2}$ Medical School, University of Crete, Heraklion, Greece; ${ }^{3}$ Department of Molecular Oncology, The Wistar Institute, Philadelphia, PA 19104;

${ }^{4}$ Department of Pathology and Laboratory Medicine, University of Pennsylvania, Philadelphia, PA 19104, USA
\end{abstract}

Contributed by D.A. Spandidos, July 28, 1995

\begin{abstract}
The nuclear phosphoprotein p53 is frequently inactivated in human cancer. Although it was previously classified as an oncoprotein, p53 has emerged as a tumor suppressor controlling cell cycle progression by regulating gene transcription. A major biochemical property of wildtype p53 is its ability to bind DNA in a sequence-specific manner. The human c-H-ras gene contains within its first intron sequences that partially match the p53 consensus binding site. We determined that these sequences represent a bona fide $\mathrm{p} 53$ element, since in vitro translated wild-type p53 recognized them with high affinity. Furthermore, wild-type p53 activated transcription from a reporter plasmid containing the $\mathrm{c}-\mathrm{H}$-ras element as an enhancer. These findings suggest that p53 regulates cellular growth by coordinate transcription of genes that suppress and promote cellular proliferation.
\end{abstract}

\section{Introduction}

The p53 gene encodes a sequence-specific transcription factor that induces cell cycle arrest or programmed cell death in response to DNA damage (1-6). In more than half of all human tumors p53 is inactivated by missense mutations (7-10). Such tumors become refractory to stimuli that would normally induce apoptosis or cell cycle arrest (11).

The protein encoded by the p53 gene has been studied extensively. The $\mathrm{N}$-terminus of $\mathrm{p} 53$ contains a transactivation domain $(12,13)$, the C-terminus a tetramerization domain (14-17), and the central region a sequence-specific DNA binding domain (18-21). The latter domain is inactivated by point mutations in human tumors (7-10).

Correspondence to: Professor D.A. Spandidos, Institute of Biological Research and Biotechnology, National Hellenic Research Foundation, 48 Vas. Constantinou Avenue. 11635 Athens, Greece

Key words: transcriptional element, H-ras, proto-oncogene, p53 tumor suppressor
The ability of p53 to regulate cell cycle progression and programmed cell death-depends on its ability to enhance expression of specific target genes (22). A number of such genes have been identified, including $\mathrm{p} 21 /$ wafl/cipl (hereafter referred to as p21), bax, gadd45 and $m d m 2$ (23-26). The p21 gene encodes an inhibitor of cyclin-dependent kinases $(27,28)$. Its expression leads to arrest of cell cycle progression $(6,23)$. The bax gene encodes an antagonist of $\mathrm{Bcl}-2$; Bax promotes, while $\mathrm{Bcl}-2$ inhibits apoptosis (24). The gadd 45 gene is implicated in DNA repair (25). In contrast to $\mathrm{p} 21$, bax and gadd45, all of which suppress cellular proliferation, the $m d m 2$ gene is a proto-oncogene (29). It encodes a protein that stimulates cell growth by inhibiting the function of two tumor suppressors: p53 and Rb $(26,30,31)$. A common feature of the p21, bax, gadd45 and $m d m 2$ genes is the presence of p53 binding sites within their regulatory elements (23-26).

The H-ras gene, like p53, is frequently mutated in human cancer (32). However, unlike p53, it is a proto-oncogene. It encodes a protein that converts GTP to GDP and acts as a molecular switch in the growth factor signal transduction pathway (33). In human cancer $\mathrm{H}$-ras or other members of the ras gene family are mutated such that their protein products promote cell proliferation (34-37).

The H-ras gene contains within its first intron a sequence that partially matches the consensus p53 binding site (38). We have established that this sequence can function as a 53 DNA binding and transcriptional element raising the possibility that expression of $\mathrm{H}-$ ras is regulated by the p53 tumor suppressor.

\section{Materials and methods}

Recombinant plasmids. Standard cloning procedures were used (39). Plasmid pGEMhp53wtB encodes human wild-type p53 (40). Plasmids pGEMhp53His175B, pGEMhp53Gln248B, pGEMhp53Trp248B and pGEMhp53His273B encode the tumor-derived p53 mutants His 175, Gln248, Trp248 and His273, respectively, and were derived from pGEMhp53wtB (40) by site-directed mutagenesis.

Plasmid pSV2hp53wtB was prepared by cloning into the SalI-BglII sites of pSV2humjun (41) a blunted EcoRI-HindIII p53 insert from pGEMhp53wtB (40). Plasmids expressing 


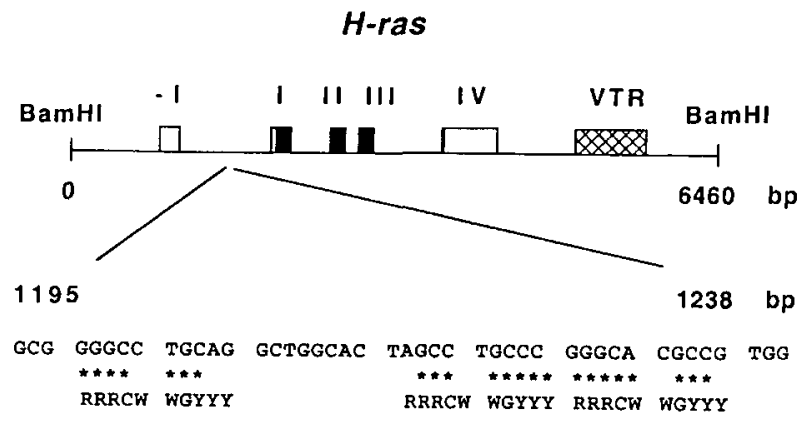

Figure 1. Organization of the human H-ras gene and position of the p53 element. The exons are represented by rectangles, the coding sequences as filled rectangles and the VTR by a crosshatched box. The nucleotide sequence of the p53 element is indicated. The p53-specific pentanucleotide repeats are demarcated by dashes and their homology to the p 53 consensus site is indicatß́d by asterisks. R, Pu; W, A/T; Y, Py. Nucleotide positions follow Capon et al (34).

tumor-derived p53 mutant proteins were similarly derived from the corresponding pGEM plasmids. A pSV2 plasmid without insert was prepared by ligating pSV2humjun (41) linearized with SalI and BglII.

Plasmid pBC12/PLseap contains the coding sequences of secreted alkaline phosphatase with no enhancer or promoter sequences (42). Plasmid pTKseap was derived from $\mathrm{pBC12}$ PLseap and contains a minimal thymidine kinase promoter (43). Plasmids pEp21/TKseap and pEras3HS/ TKseap have one copy of oligonucleotides Ep21 and Eras3HS, respectively, cloned in the EcoRV site of pTKseap just upstream of the minimal thymidine kinase promoter. The sequences of oligonucleotides Ep21 and Eras3HS are: CCCGAACA-TGTCC-CAACA-TGTTG-GGG and GCGGGGCC-TGCAG-GCTGGCAC-TAGCC-TGCCC-GGGCACGCCG-TGG, respectively. The repeats recognized by $\mathrm{p} 53$ are underlined.

DNA binding assays. Plasmids of the pGEM series were used to generate in vitro translated p53 proteins $(21,40,44)$. These proteins were subsequently incubated with ${ }^{32} \mathrm{P}$-labeled oligonucleotides and subjected to electrophoresis as previously described $(21,40,44)$. Oligonucleotide TF3 is a non-specific DNA (44). Antibody PAb421 was obtained from Oncogene Science (Uniondale, NY).

Transcription assays. Saos- 2 cells were transiently transfected by calcium phosphate precipitation (43). Each transfection was performed using $10 \mu \mathrm{g}$ of the pSV2 series plasmids driving p53 expression and $20 \mu \mathrm{g}$ of the reporter plasmids. Alkaline phosphatase activity was determined $48 \mathrm{~h}$ later as described (43).

\section{Results}

Identification of a putative 553 element in $H$-ras. DNA sites recognized by the $\mathrm{p} 53$ tumor suppressor consist of two halfsites, which may be contiguous or separated by as much as 21 nucleotides $(38,40,45)$. Each half-site is ten nucleotides long and contains two pentamer repeats arranged head-tohead. The sequence of the optimal half-site is GGGCA-
TGTCC $(38,44)$. Wild-type $p 53$, however, can also bind to sites that differ from the optimal sequence. It has been suggested that $\mathrm{p} 53$ recognizes DNAs containing two halfsites that fit the consensus PuPuPuC(A/T)-(A/T)GPyPyPy, where $\mathrm{Pu}$ and $\mathrm{Py}$, are purines and pyrimidines, respectively (45).

A computer search of the genes in the GenBank database has revealed that human $\mathrm{H}-\mathrm{ras}$ contains two consecutive pentanucleotides that fit the $\mathrm{p} 53$ consensus (38). We were intrigued by this observation and inspected the adjacent DNA sequences. We were able to identify four more pentanucleotides that together with the ones previously identified, form three putative p53 half-sites (Fig. 1). Two of these halfsites are contiguous, while the third one is located 8 nucleotides upstream. Although none of the half-sites fit the consensus PuPuPuC(A/T)-(A/T)GPyPyPy, their close juxtaposition raises the possibility that they may be recognized by human $\mathrm{p} 53$.

Recognition of the putative $H$-ras element by $p 53$. The ability of human p53 to bind the putative H-ras element was examined in an electrophoretic mobility shift assay. In vitro translated wild-type p53 bound a ${ }^{32} \mathrm{P}$-labeled oligonucleotide (Eras3HS) containing all three half-sites of $\mathrm{H}$-ras (Fig. 2). Binding was enhanced by antibody PAb421, which recognizes the $\mathrm{p} 53 \mathrm{C}$-terminus and is known to switch p53 into a conformation with high affinity for DNA $(21,40,44$, 46,47). Furthermore, PAb421 supershifted the p53/DNA complex, thereby confirming the identity of the DNA binding protein as p53. To determine if recognition of the ${ }^{32} \mathrm{P}$-labeled $\mathrm{H}$-ras DNA by wild-type p53 was sequence-specific, the binding reaction was performed in the presence of 500 -fold excess of non-radioactive competitor DNAs. Binding was competed by oligonucleotide Ep21, which contains the p53 element of the p21 gene (23), but not by oligonucleotide TF3, which does not contain a p53 DNA site. Binding was also competed, as expected, by oligonucleotide Eras3HS. In a related experiment we examined binding of $\mathrm{p} 53$ to ${ }^{32} \mathrm{P}$ labeled oligonucleotide Ep21. Wild-type p53 recognized this DNA and furthermore binding was enhanced by antibody PAb421. Excess of non-radioactive Eras3HS DNA competed 


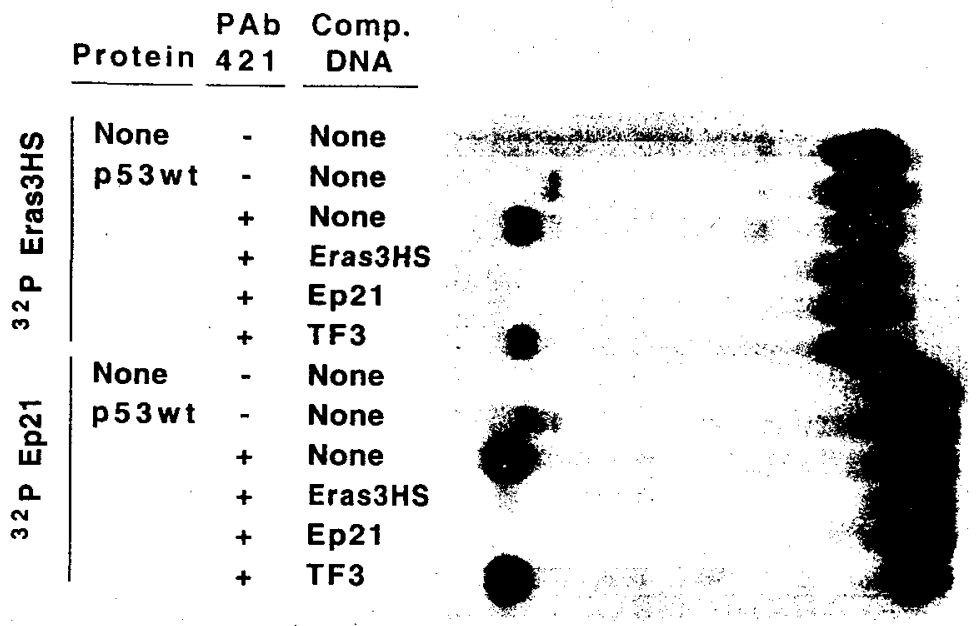

Figure 2. Wild-type p53 recognizes an element of the H-ras gene. In vitro translated wild-type p53 was incubated with ${ }^{32} \mathrm{P}$-labeled oligonucleotides Eras3HS or Ep21. Where indicated 500-fold excess unlabeled specific (Ep21) or non-specific (TF3) competitor DNA and/or antibody PAb421 were added. The reactions were resolved on native polyacrylamide gels.

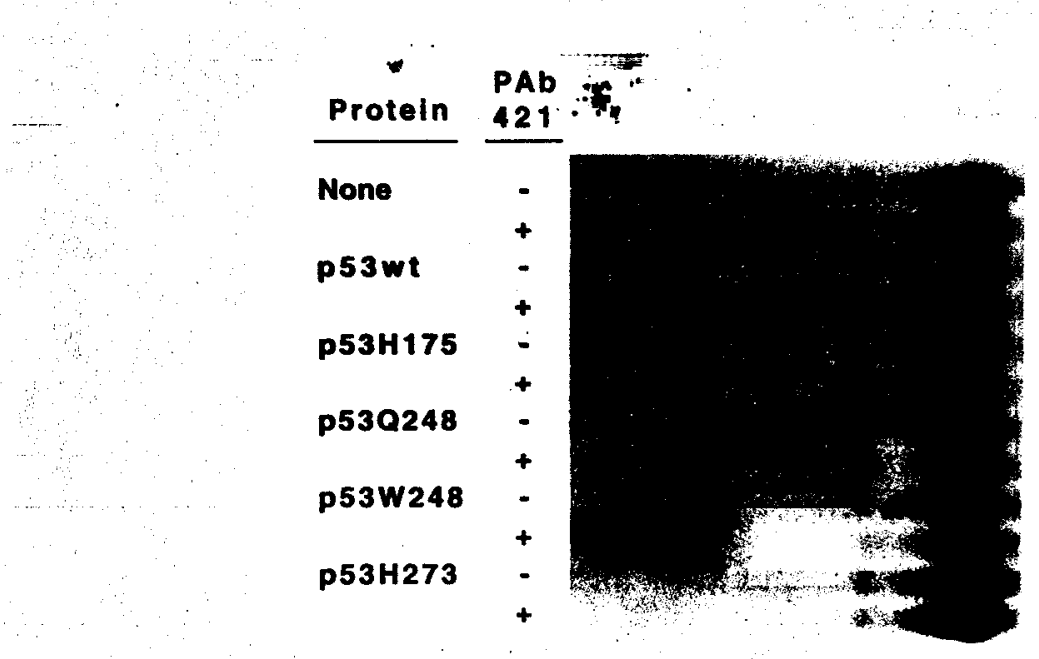

Figure 3. Binding of 553 to the H-ras element requires an intact sequence-specific DNA binding domain. In vitro translated wild-type p53 or tumor-derived p53 mutants were incubated with ${ }^{32} \mathrm{P}$-labeled oligonucleotide Eras $3 \mathrm{HS}$ and then resolved on native polyacrylamide gels. Where indicated the binding reactions were performed in the presence of $0.1 \mu \mathrm{g}$ antibody PAb421. H, His; Q, Gln; W, Trp.

for binding of $\mathrm{p} 53$ to labeled Ep21, while excess of a nonspecific DNA (oligonucleotide TF3) did not (Fig. 2). We conclude that $\mathrm{p} 53$ recognizes with specificity an element within the human H-ras gene. Furthermore, the affinity of p53 for this element is comparable to the well-characterized p53 element of the $\mathrm{p} 21$ gene.

Wild-type $p 53$ contains a sequence-specific DNA binding domain within residues $90-290$ and a sequence-independent DNA binding domain within its $\mathrm{C}$-terminal 30 amino acids $(18-21,48)$. To determine which domain recognizes the H-ras element, we examined tumor-derived p53 mutants, which carry single amino acid substitutions within the sequencespecific DNA binding domain. Mutants His 175, Gln248, Trp248 and His 273 are very frequently associated with human cancer (7-10). Their names indicate the residue encoded by the mutated codon and the codon number. All these mutants were impaired relative to wild-type p53 in their ability to bind the Eras3HS oligonucleotide (Fig. 3), suggesting that wild-type p53 recognizes the H-ras element through its sequence-specific DNA binding domain. 
Table I. The $\mathrm{H}$-ras p 53 clement functions as a p 53 -dependent transcriptional enhancer.

\begin{tabular}{llc}
\hline Enhancer/Promoter & Expressed protein & Activity \\
\hline Eras3HS/TK & Wild-type p53 & $175.7 \pm 3.0$ \\
& p53His273 & $59.7 \pm 2.0$ \\
& p53Trp248 & $62.3 \pm 13.0$ \\
& None & $40.0 \pm 2.6$ \\
Ep21/TK & Wild-type p53 & $1797.3 \pm 420.7$ \\
& p53His273 & $91.3 \pm 7.2$ \\
& p53Trp248 & $84.0 \pm 3.2$ \\
& None & $49.7 \pm 7.7$ \\
None/TK & Wild-type p53 & $32.0 \pm 4.0$ \\
None/None & Wild-type p53 & $0.0 \pm 0.0$ \\
\hline
\end{tabular}

Wild-type p53 and the tumor-derived p53 mutants His 273 and Trp248 were assayed for the ability to activate transcription from reporter plasmids containing Eras3HS or Ep21 enhancerelements. As controls we used a pSV2 expression plasmid without insert (expressing no protein) and reporter plasmids with no enhancer or no promoter. The results are presented as means \pm 1 SE in arbitrary units. TK, thymidine kinase.

The H-ras p53 element functions as a transcriptional enhancer. Wild-type p53 is a known transcriptional activator $(12,13)$. Since the H-ras element is specifically recognized by $\mathrm{p} 53$, we examined whether it could function as a p53dependent transcriptional enhancer. Reporter plasmids were constructed that contained the H-ras or the p21 or no p53 element upstream of a minimal promoter driving expression of secreted alkaline phosphatase. These reporters together with plasmids directing expression of p53 were transiently transfected into Saos-2 osteosarcoma cells, which lack endogenous p53 (49). Wild-type p53 activated transcription from the reporter plasmids containing $\mathrm{H}$-ras or $\mathrm{p} 21$ elements, but not from reporters lacking a p53 element or lacking a promoter (Table I). Consistent with their compromised DNA binding activities, the tumor-derived p 53 mutants His 273 and Trp248 failed to activate transcription from any of the reporter plasmids tested. We conclude that the $\mathrm{H}$-ras element, although not as potent as the $\mathrm{p} 21$ element, can serve as a p53-dependent transcriptional enhancer.

\section{Discussion}

The p53 tumor suppressor controls cell cycle progression by regulating gene expression (22). The genes whose expression is induced by p 53 invariably contain p 53 binding sites within thcir regulatory regions (23-26). Interestingly, $\mathrm{H}-$ ras contains within its first intron sequences with homology to the p53 consensus recognition site (38). We demonstrated in this study that wild-type p53 recognized these sequences with specificity and with affinity comparable to its affinity for the bona fide p21 element. Furthermore, the H-ras element functioned as a p53-dependent transcriptional enhancer in the context of an artificial reporter plasmid, albeit with a lower efficiency than the p 21 clement. We have therefore

\section{H-ras}

GGGCC TGCAG GCTGGCAC TAGCC TGCCC GGGCA CGCCE

TGGCGCGCTCCGCCGTGGC AGACC TGTTC

\section{$m d m 2$}

GGTCA AGTTG GGACA EGTCC GGCGTCGgCTGTCGgAG GAGCT A AGTCC TGACA TGTCT

$p 21$

GAACA TGTCC CAACA TGTTG

gadd 45

GAACA TGTCT AAGCA TGCTG

$b a x$

TCACA AGTTA G AGACA AGCCN

Figure 4. Organization of the H-ras, $m d m 2, p 21$, gadd45 and bax p53 elements. The specific pentanucleotide repeats recognized by $\mathrm{p} 53$ are underlined. The H-ras and $m d m 2$ genes contain a fourth p53 half-site (in italics), whose functional significance has not been investigated yet.

established the presence of a p53-dependent transcriptional -element within the $\mathrm{H}$-ras gene. The most likely interpretation of our results is that $\mathrm{p} 53$ is a physiological regulator of $\mathrm{H}$-ras expression.

Activation of H-ras expression by p53 may seem to be a paradox, since $\mathrm{p} 53$ is a tumor suppressor $(50,51)$ and $\mathrm{H}$-ras a proto-oncogene (32-37). However, precedence has already been established for activation of proto-oncogenes by $\mathrm{p} 53$. Wild-type p53 induces expression of $m d m 2$, whose protein product functions as an oncoprotein by inhibiting the tumor suppressing activities of both p53 and Rb (26,29-31). Amplification of the $m d m 2$ gene or enhanced translation are frequently associated with human tumors $(52,53)$. Wild-type p53 may therefore induce expression of two proto-oncogenes frequently associated with human cancer: $m d m 2$ and $\mathrm{H}$-ras.

The list of genes known to be regulated by $\mathrm{p} 53$ includes $\mathrm{p} 21$, gadd45, bax, mdm2 and H-ras (23-26). The p21 gene encodes an inhibitor of cyclin-dependent kinases $(27,28)$. Its expression arrests cellular growth $(6,23)$. The gadd45 gene participates in the cellular response to DNA damage (25), while bax stimulates programmed cell death (24). None of these three genes stimulate cell proliferation. In contrast, $m d m 2$ and H-ras are proto-oncogenes. Interestingly, there are certain similarities in the organization of the half-sites in the p53 elements of the H-ras and $m d m 2$ genes, which are not shared with the p 53 elements of the other genes targeted by p53. In H-ras there are three half-sites (Fig. 4). Two of them are contiguous, while the third one is 8 nucleotides upstream of the first two. In $m d m 2$ there are again three half-sites (26). Two are contiguous, while the third one is 28 nucleotides downstream. In contrast to $\mathrm{H}$-ras and $m d m 2$, the half-sites in the $\mathrm{p} 21$, gadd45 and bax elements are contiguous (23-25). The organization of the half-sites affects the ability of p53 to recognize these elements. Wild-type p53 reversibly switches between two conformations $(21,40,44,46,47)$. In the 'inactive' $\mathrm{T}$ state wild-type p53 adopts dihedral symmetry, 
en that it cannot recognize contiguous half-sites. It can recognize, however, non-contiguous half-sites (40). In the 'activated' $R$ state wild-type p53 is not locked in a dihedrally symmetric state and its DNA binding domains can recognize even contiguous half-sites (40). Thus, the presence of noncontiguous p53 half-sites in the H-ras and $m d m 2$ genes may allow their transcription to be regulated by p53 even when it is in the 'inactive' $T$ state.

The p53 elēment in H-ras is contained within the first intron. The significance of this is not understood at this time. Interestingly, the p53 element of $m d m 2$ is also within the first intron (26). Transcription of $m d m 2$ is initiated either at a promoter upstream of the first exon or at a promoter within the first intron. Wild-type p53 activates transcription only from the second promoter (54). Transcripts initiating at both promoters contain the entire $m d m 2$ coding sequence, but differ in the efficiency with which translation is initiated at codon 1. Thus, the transcripts that include the first exon express mostly an $\mathrm{N}$-terminally truncated $\mathrm{Mdm} 2$ protein, while the transcripts whose expression is induced by $\mathrm{p} 53$ express full-length $\mathrm{Mdm} 2$ (55). The two forms of $\mathrm{Mdm} 2$ differ in their functional properties. The full-length form, but not the truncated, can associate with the transcription activation domain of p53 closing a negative feedback loop, whereby p53 activates $m d m 2$ transcription and $\mathrm{Mdm} 2$ suppresses the transcriptional activity of p53 (26). It remains to be determined whether p53 induces expression of transcripts initiating at the first intron of H-ras, and whether any functional significance can be ascribed to such transcripts.

In conclusion these studies demonstrate the presence of a p53 transcriptional element in the H-ras gene. The p53 tumor suppressor may therefore exert its cellular effects by coordinate activation of genes that suppress and induce cell proliferation.

\section{Acknowledgements}

The authors thank Jennifer Waterman and Jill Shenk for preparing the plasmids. Also Dr Giovanni Rovera and Dr Elena Stavridi for their support. Saos-2 cells were kindly provided by Dr Stephen Friend. Financial support to T.D.H. was provided by Bayer A.G.

\section{References}

1. Maltzman W and Czyzyk L: UV irradiation stimulates levels of p53 cellular tumor antigen in nontransformed mouse cells. Mol Cell Biol 4: 1689-1694, 1984.

2. Kastan MB, Onyekwere O, Sidransky D, Vogelstein B and Craig RW: Participation of p53 protein in the cellular response to DNA damage. Cancer Res 51: 6304-6311, 1991.

3. Lowe SW, Ruley HE, Jacks T and Housman DE: p53-dependent apoptosis modulates the cytotoxicity of anticancer agents. Cell 74: 957-967, 1993.

4. Lowe SW, Schmitt EM, Smith SW, Osborne BA and Jacks T: p53 is required for radiation-induced apoptosis in mouse thymocytes. Nature 362:847-849, 1993.

5. Clarke AR, Purdie CA, Harrison DJ, Morris RG, Bird CC, Hooper ML and Wyllie AH: Thymocyte apoptosis induced by p53-dependent and independent pathways. Nature 362: 849. $852,1993$.

6. Leonardo AD, Linke SP, Clarkin K and Wahl GM: DNA damage triggers a prolonged p53-dependent Gl arrest and longterm induction of Cipl in normal human fibroblasts. Genes Dev 8: 2540-2551, 1994
7. Harris CC: p53: At the crossroads of molecular carcinogenesis and risk assessment. Science 262: 1980-1981, 1993.

8. Friend S: p53: A glimpse at the puppet behind the shadow play Science 265: 334-335, 1994.

9. Bargonetti J, Friedman PN, Kern SE, Vogelstein B and Prives C: Wild-type but not mutant p53 immunopurified proteins bind to sequences adjacent to the SV40 origin of replication. Cell 65: 1083-1091, 1991.

10. Kem SE, Kinzler KW, Bruskin A, Jarosz D, Friedman P, Prives C and Vogelstein B: Identification of $\mathrm{p} 53$ as a sequence-specific DNA-binding protein. Science 252: 1708-1711, 1991.

11. Fisher DE: Apoptosis in cancer therapy: Crossing the threshold Cell 78: 539-542, 1994.

12. Fields $S$ and Jang SK: Presence of a potent transcription activating sequence in the p53 protein. Science 249: 1046-1049, 1990.

13. Unger T, Nau MN, Segal S and Minna JD: p53: a transdominant regulator of transcription whose function is ablated by mutations occurring in human cancer. EMBO J 11: 1383-1390, 1992.

14. Milner J, Medcalf EA and Cook AC: Tumor suppressor p53: analysis of wild-type and mutant p53 complexes. Mol Cell Biol 11: 12-19, 1991

15. Stürzbecher HW, Brain R, Addison C, Rudge K, Remm M, Grimaldi $M$, Keenan $E$ and Jenkins JR: A C-terminal $\alpha$-helix plus basic region motif is the major structural determinant of p53 tetramerization. Oncogene 7: 1513-1523, 1992.

16. Sakamoto H, Lewis MS, Kodama H, Appella E and Sakaguchi K: Specific sequences from the carboxyl terminus of human p53 gene product form anti-parallel tetramers in solution. Proc Natl Acad Sci USA 91: 8974-8978, 1994.

17. Wang P, Reed M, Wang Y, Mayr G, Stenger JE, Anderson ME, Schwedes JF and Tegtmeyer P: p53 domains: Structure, oligomerization and transformation. Mol Cell Biol 14: 5182 $5191,1994$.

18. Bargonetti J, Manfredi JJ, Chen X, Marshak DR and Prives C: A proteolytic fragment from the central region of $\mathrm{p} 53$ has marked sequence-specific DNA-binding activity when generated from wild-type but not from oncogenic mutant p53 protein. Genes Dev 7: 2565-2574, 1993.

19. Pavletich NP, Chambers KA and Pabo CO: The DNA-binding domain of p53 contains the four conserved regions and the major mutation hot spots. Genes Dev 7: 2556-2564, 1993.

20. Wang Y, Reed M, Wang P, Stenger JE, Mayr G, Anderson ME, Schwedes JF and Tegtmeyer P: p53 domains: identification and characterization of two autonomous DNA-binding regions. Genes Dev 7: 2575-2586, 1993.

21. Halazonetis TD and Kandil AN: Conformational shifts propagate from the oligomerization domain of $p 53$ to its tetrameric DNA binding domain and restore DNA binding to select p53 mutants. EMBO J 12: 5057-5064, 1993.

22. Pietenpol JA, Tokino T, Thiagalingam S, El-Deiry WS, Kinzler KW and Vogelstein B: Sequence-specific transcriptional activation is essential for growth suppression by p53. Proc Natl Acad Sci USA 91: 1998-2002, 1994.

23. El-Deiry WS, Tokino T, Velculescu VE, Levy DB, Parsons R, Trent JM, Lin D, Mercer WE, Kinzler KW and Vogelstein B: WAF1, a potential mediator of p53 tumor suppression. Cell 75: 817-825, 1993.

24. Miyashita T and Reed JC: Tumor suppressor p53 is a direct transcriptional activator of the human bax gene. Cell 80: 293$299,1995$.

25. Kastan MB, Zhan Q, El-Deiry WS, Carrier F, Jacks T, Walsh WV, Plunkett BS, Vogelstein B and Fornace Jr AJ: A mammalian cell cycle checkpoint pathway utilizing p53 and GADD45 is defective in ataxia-telangiectasia. Cell 71: 587-597, 1992.

26. Wu X, Bayle JH, Olson D and Levine AJ: The p53-mdm2 autoregulatory feedback loop. Genes Dev 7: 1126-1132, 1993

27. Harper JW, Adami GR, Wei N, Keyomarsi K and Elledge SJ: The p2l cdk-interacting protein $\mathrm{Cipl}$ is a potent inhibitor of $\mathrm{Gl}$ cyclin-dependent kinases. Cell 75: 805-816, 1993

28. Xiong $Y$, Hannon $G J$, Zhang $H$, Casso $D$, Kobayashi $R$ and Beach D: p21 is a universal inhibitor of cyclin kinases. Nature 366: 701-704, 1993.

29. Fakharzadeh SS, Trusko SP and George DL: Tumorigenic potential associated with enhanced expression of a gene that is amplified in a mouse tumor cell line. EMBO J 10: 1565-1569, 1991

30. Martin K, Trouche D, Hagemeier C, Sorensen TS, La Thangue NB and Kouzarides T: Stimulation of E2F1/DPI transcriptional activity by MDM2 oncoprotein. Nature 375: 691-694, 1995 
31. Xiao ZX, Chen J, Levine AJ, Modjtahedi N, Xing J, Sellers WR and Livingston DM: Interaction between the retinoblastoma protein and the oncoprotein MDM2. Nature 375: 694-698, 1995.

32. Kiaris $H$ and Spandidos DA: Mutations of H-ras genes in human tumors. Int J Oncol 7: 413-421, 1995.

33. Pawson T: Protein modules and signalling networks. Nature 373: 573-580, 1995.

34. Capon DJ, Chen EY, Levinson AD, Seeburg PH and Goeddel DV: Complete nucleotide sequences of the T24 human bladder carcinoma oncogene and its normal homologue. Nature 302: 33$37,1983$.

35. Tabin CJ, Bradley SM, Bargmann CI, Weinberg RA, Papageorge AG, Scolnick EM, Dhar R, Lowy DR and Chang EH: Mechanism of activation of a human oncogene. Nature 300 : 143-149, 1982

36. Reddy PE, Reynolds RK, Santos E and Barbacid M: A point mutation is responsible for the acquisition of transforming properties by the T24 human bladder carcinoma oncogene. Nature 300: 149-152, 1982.

37. Spandidos DA and Wilkie NM: Malignant transformation of early passage rodent cells by a single mutated human oncogene. Nature 310: 469-475, 1984

38. Funk WD, Pak DT, Karas RH, Wright WE and Shay JW: A transcriptionally active DNA-binding site for human $\mathrm{p} 53$ protein complexes. Mol Cell Biol 12: 2866-2871, 1992.

39. Ausubel FM, Brent R, Kingston RE, Moore DD, Seidman JG, Smith JA and Struhl K: Current Protocols in Molecular Biology. Greene/Wiley Publishing Associates, New York, 1994.

40. Waterman JLF, Shenk JL and Halazonetis TD: The dihedral symmetry of the p53 tetramerization domain mandates a conformational switch upon DNA binding. EMBO J 14: 512$519,1995$.

41. Zhang K, Chaillet JR, Perkins LA, Halazonetis TD and

- Perrimon N: Drosophila homolog of the mammalian jun oncogene is expressed during embryonic development and activates transcription in mammalian cells. Proc Natl Acad Sci USA 87: 6281-6285, 1990.

42. Berger J, Hauber J, Hauber R, Geiger R and Cullen BR: Secreted placental alkaline phosphatase: a powerful new quantitative indicator of gene expression in eukaryotic cells. Gene 66: 1-10, 1988 .
43. Halazonetis TD: An enhancer 'core' DNA-binding and transcriptional activity is induced upon transformation of rat cmbryo fibroblasts. Anticancer Res 12: 285-292, 1992.

44. Halazonetis TD, Davis LJ and Kandil AN: Wild-type p53 adopts a 'mutanl'-like conformation when bound to DNA EMBO J 12: 1021-1028, 1993.

45. El-Deiry WS, Kern SE, Pietenpol JA, Kinzler KW and Vogelstein B: Definition of a consensus binding site for $\mathrm{p} 53$. Nature Genetics 1: 45-49, 1992

46. Hupp TR, Mcek DW, Midgley CA and Lane DP: Regulation of the specific DNA binding function of p53. Cell 71: 875-886, 1992

47. Hupp TR and Lane DP: Allosteric activation of latent p53 tetramers. Curr Biol 4: 865-875, 1994

48. Oberosler P. Hloch P, Ramsperger U and Stahl H: p53. catalyzed annealing of complementary single-stranded nucleic acids. EMBO J 12:2389-2396, 1993

49. Diller L, Kassel J, Nelson CE, Gryka MA, Litwak G, Gebhardt M, Bressac B, Ozturk M, Baker SJ, Vogelstein B and Friend SH: p53 functions as a cell cycle control protein in osteosarcomas. Mol Cell Biol 10: 5772-5781, 1990.

50. Eliyahu D, Michalovitz D, Eliyahu S, Pinhasi-Kimhi $O$ and Oren M: Wild-type p53 can inhibit oncogene-mediated focus formation. Proc Natl Acad Sci USA 86: 8763-8767, 1989.

51. Finlay CA, Hinds PW and Levine AJ: The p53 proto-oncogene can act as a suppressor of transformation. Cell 57: 1083-1093, 1989

52. Oliner JD, Kinzler KW, Meltzer PS, George D and Vogelstein B: Amplification of a gene encoding a p53-associated protein in human sarcomas. Nature 358: 80-83, 1992.

53. Landers JE, Haines DS, Strauss JF and George D: Enhanced translation: A novel mechanism of $m d m 2$ oncogene overexpression identified in human tumor cells. Oncogene 9: 2745-2750, 1994

54. Juven T, Barak Y, Zauberman A, George DL and Oren M: Wild-type $\mathrm{p}^{3} 3$ can mediate sequence-specific transactivation of an internal promoter within the $m d m 2$ gene. Oncogene 8: 3411 3416, 1993.

55. Barak Y, Gottlieb E, Juven-Gershon T and Oren M: Regulation of $m d m 2$ expression by $\mathrm{p} 53$ : alternative promoters produce transcripts with nonidentical translation potential. Genes Dev 8: 1739-1749, 1994. 